\title{
Anti-Inflammatory Effects of Methanol Extract, Hexane, Ethyl Acetate, and Butanol Fraction of Piper crocatum Ruiz \& Pav Leaves on Lipopolysaccharide-induced RAW 264.7 Cells
}

\author{
Nilda Lely ${ }^{1,3}$, Helmi Arifin ${ }^{2}$, Yufri Aldi ${ }^{2}$, Fatma Sri Wahyuni ${ }^{2, *}$
}

Nilda Lely ${ }^{1,3}$, Helmi Arifin ${ }^{2}$, Yufri Aldi $^{2}$, Fatma Sri Wahyuni ${ }^{2, *}$

'Postgraduate Student, Faculty of Pharmacy, Universitas Andalas, Padang, Sumatera Barat 25163, INDONESIA.

${ }^{2}$ Faculty of Pharmacy, Universitas Andalas, Padang, Sumatera Barat 25163, INDONESIA. ${ }^{3}$ STIFI Bhakti Pertiwi Palembang. Jl. Ariodillah III No.22A, RT.27/RW.9, 20 Ilir D. IV, Ilir Tim. Kota Palembang, Sumatera Selatan 30128 , INDONESIA.

\section{Correspondence}

\section{Fatma Sri Wahyun}

Faculty of Pharmacy, Universitas Andalas, Kampus Limau Manis, Padang 25163, INDONESIA.

E-mail: fatmasriwahyuni@phar.unand.ac.id History

- Submission Date: 26-07-2021;

- Review completed: 12-08-2021;

- Accepted Date: 23-08-2021.

DOI : 10.5530/pj.2021.13.169

Article Available online http://www.phcogj.com/v13/i6

\section{Copyright}

(C) 2021 Phcogi.Com. This is an openaccess article distributed under the terms of the Creative Commons Attribution 4.0 International license.

\begin{abstract}
Piper crocatum Ruiz \& Pav is a traditional Indonesian plant that is empirically used to treat various diseases. Several studies have stated that Piper crocatum leaves extract has anti-inflammatory effects. Piper crocatum leaves contain different secondary metabolites alkaloids, flavonoids, tannin-polyphenols, steroids, terpenoids, and saponins. The purpose of this study was to determine the anti-inflammatory effect of Piper crocatum leaves extract and fraction on the production of nitric oxide in lipopolysaccharideinduced RAW 264.7 cells. Anti-inflammatory effect of methanol extract of Piper crocatum leaves (MEPC), n-hexane fraction of Piper crocatum leaves (HFPC), ethyl acetate fraction of Piper crocatum leaves (EAFPC), and n-butanol fraction of Piper crocatum leaves (BFPC) against RAW 264 cell macrophages, 7 Lipopolysaccharide-induced (LPS). Extraction of Piper crocatum leaves was the maceration method. Cell viability was determined by the MTT method in the concentration range of $12.5 ; 25 ; 50 ; 100 ; 200 \mathrm{ug} /$ $\mathrm{mL}$. The anti-inflammatory effects of MEPC, HFPC, EAFPC and BFPC were tested against nitric oxide (NO) production inhibition in LPS-induced RAW 264.7 macrophage cells. NO levels were determined by the NO Colorimetric Assay Kit as measured by the ELISA plate reader. The viability test of MEPC, HFPC, EAFPC, and BFPC from Piper crocatum leaves showed the concentrations that gave the percentage of viability above $80 \%$ were concentrations of 100,50 , and $25 \mathrm{~g} / \mathrm{mL}$. MEPC, HFPC, EAFPC, and BFPC at concentrations of $100,50,25 \mu \mathrm{g} / \mathrm{mL}$ could significantly inhibit NO production with $p<0.05(p=0.000)$. The highest NO production inhibition effect was on EAFPC. MEPC, HFPC, EAFPC, and BFPC have antiinflammatory effects, with the highest effect on EAFPC.
\end{abstract}

Key words: Piper crocatum, Anti-inflammatory effect, LPS, Nitric oxide.

\section{INTRODUCTION}

Inflammation is a physiological response to stimuli such as infection and tissue injury. This stimulation causes the release of inflammatory mediators such as nitric oxide, histamine, serotonin, bradykinin, and prostaglandins which cause an inflammatory reaction in the form of heat, pain, redness, swelling, and accompanied by impaired function.

Lipopolysaccharide is a component of the cell wall of gram-negative bacteria, the polyclonal activator of the immune system, stimulates the release of various inflammatory mediators, including nitric oxide (NO), prostaglandin E2, proinflammatory cytokines such as IL-1, IL-6, IL-12, IL-18, TNF- $\alpha$ and TNF- $\beta$. Activated macrophages are the main effector cells in the host defense against bacteria through the production of nitric oxide (NO), which is cytotoxic to parasites. Nitric oxide (NO) and reactive oxygen species exert several modulating effects on inflammation and play a key role in regulating the immune response. $\mathrm{NO}$ is the main product controlled by nitric oxide synthase (NOS), such as iNOS (inducible nitric oxide synthase). iNOS is induced in macrophages so that its activation leads to organ destruction in several inflammatory and autoimmune diseases. ${ }^{2,3}$

Piper crocatum is one of the plants used by the people of Indonesia as traditional medicine. Empirically red betel is often used to treat diabetes mellitus, hepatitis, kidney stones, lowering cholesterol, preventing stroke, gout, hypertension, coronary heart disease, uterine cancer, breast cancer, hemorrhoids, tuberculosis, toothache medicine, canker sores, body odor., venereal disease, inflammation of the liver, inflammation of the prostate, inflammation of the eye, vaginal discharge, ulcers, fatigue, joint pain, smoothing the skin, inflammation of the ear, cough medicine, inflammation of the lungs, inflammation of the throat, inflammation of the gums, inflammation of the breast, nose bleed, and coughing up blood. ${ }^{4}$

Research conducted stated that the methanol extract of Piper crocatum leaves showed anti-inflammatory effects. ${ }^{5,6,7}$ The ethanol extract of Piper crocatum has an antioxidant effect. ${ }^{8}$ Piper crocatum contains various secondary metabolites. Identifying phytochemical components from red betel leaf contains flavonoids, alkaloids, tanninpolyphenols, steroids, terpenoids and saponins. ${ }^{910}$

\section{MATERIALS AND METHODS}

\section{Chemicals and Reagents}

Methanol, n-hexane, ethyl acetate, n-butanol, RAW cells 264.7 (CCRC UGM), DMSO, dulbecco's Modified Eagle Medium (DMEM) (Gibco), penicillin-streptomycin (gibco), Fetal Bovine Serum (FBS) ( Sigma), Phosphate buffered saline (PBS)(Sigma), 3-(4,5-dimethylthiazol-2-yl)-2, 5-diphenyltetrazolium bromide (MTT) (eBioscience), dimethylsulfoxide, wash buffer lipopolysaccharide (eBioscience), dexamethasone (Dexamedica), NO Colorimetric Assay Kit (Elabscience),

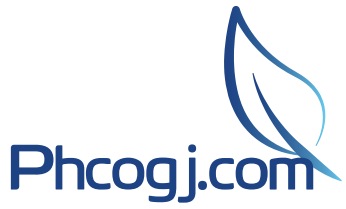

Cite this article: Lely $\mathrm{N}$, Arifin $\mathrm{H}$, Aldi $\mathrm{Y}$, Wahyuni FS. Anti-Inflammatory Effects of Methanol Extract, Hexane, Ethyl Acetate, and Butanol Fraction of Piper crocatum Ruiz \& Pav Leaves on Lipopolysaccharide-induced RAW 264.7 Cells. Pharmacogn J. 2021;13(6): 1341-1346. 
Lely N, et al:: Anti-Inflammatory Effects of Methanol Extract, Hexane, Ethyl Acetate, and Butanol Fraction of Piper crocatum Ruiz \& Pav Leaves on Lipopolysaccharideinduced RAW 264.7 Cells

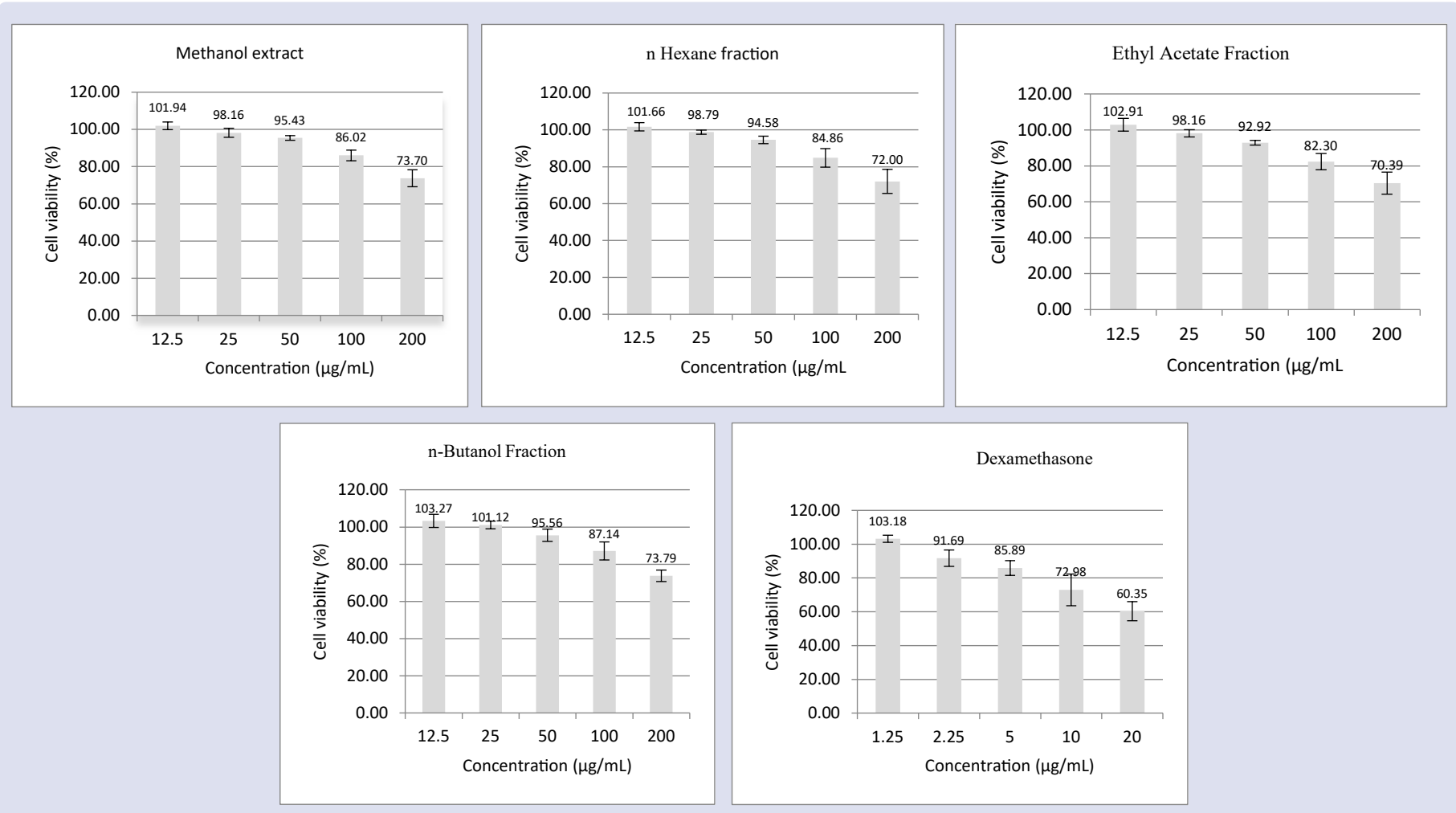

Figure 1: The mean percentage of live cells of MEPC, HFPC, EAFPC, and BFPC of Piper crocatum Ruiz \& Pav leaf and dexamethasone in RAW cells 264.7.

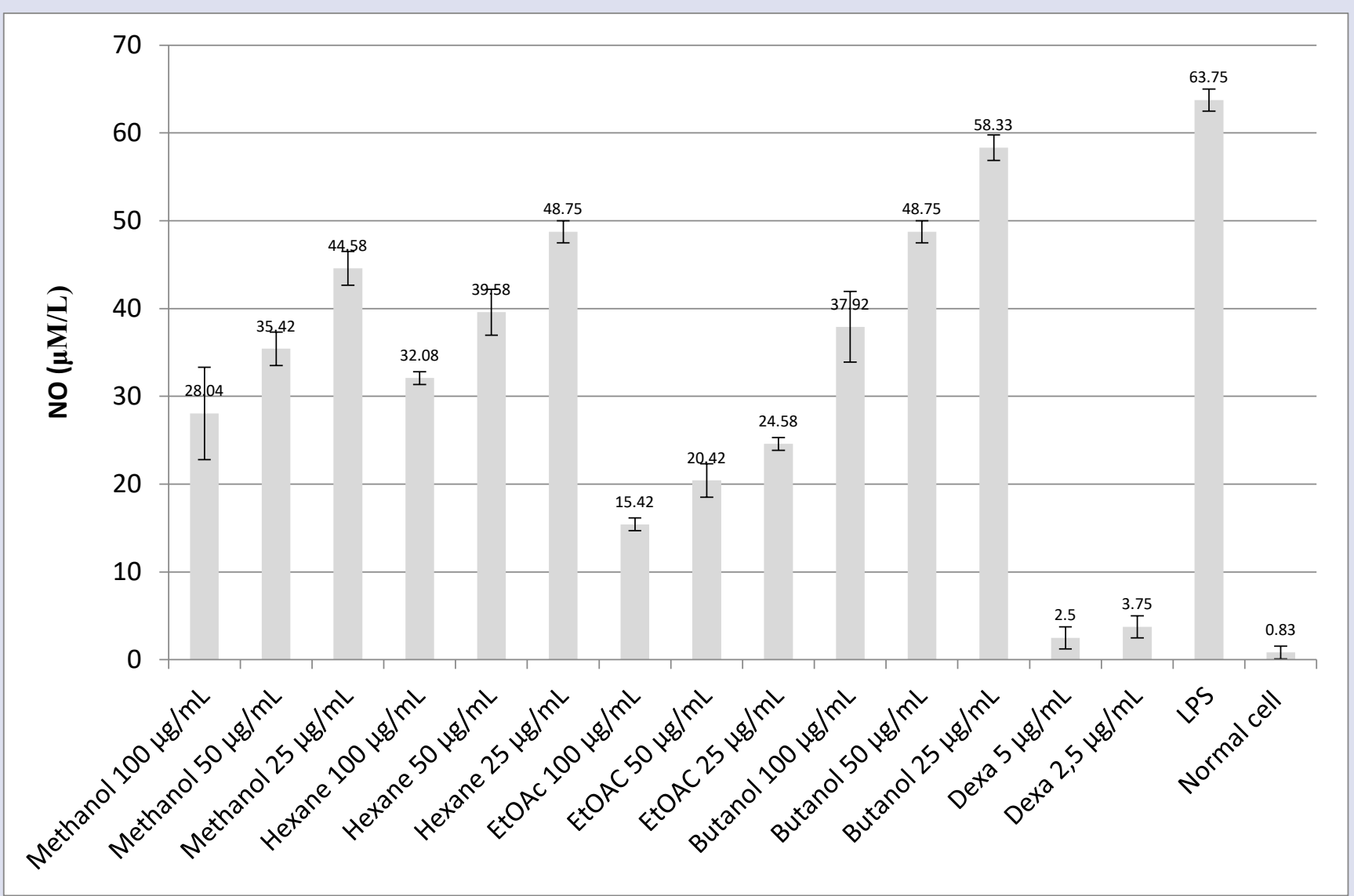

Figure 2: NO levels of MEPC, HFPC, EAFPC, and BFPC of red betel leaf, dexamethasone, negative control, in LPS-induced RAW 264.7 cells, and normal cells. 
Table 1: NO levels of MEPC, HFPC, EAFPC and BFPC of red betel leaf, dexamethasone, negative control, in LPS-induced RAW 264.7 cells, and normal cells.

\begin{tabular}{lll}
\hline & Sample & $\begin{array}{l}\text { Average } \\
(\mu \mathrm{mol} / \mathrm{L})\end{array}$ \\
\hline 1 & Methanol $100 \mu \mathrm{g} / \mathrm{mL}$ & $28,04 \pm 5,268$ \\
2 & Methanol $50 \mu \mathrm{g} / \mathrm{mL}$ & $35,42 \pm 1,909$ \\
3 & Methanol $25 \mu \mathrm{g} / \mathrm{mL}$ & $44,58 \pm 1,909$ \\
4 & n-Hexane $100 \mu \mathrm{g} / \mathrm{mL}$ & $32,08 \pm 0,722$ \\
5 & $\mathrm{n}$-Hexane $50 \mu \mathrm{g} / \mathrm{mL}$ & $39,58 \pm 2,602$ \\
6 & n-Hexane $25 \mu \mathrm{g} / \mathrm{mL}$ & $48,75 \pm 1,250$ \\
7 & Ethyl Acetate $100 \mu \mathrm{g} / \mathrm{mL}$ & $15,42 \pm 0,722$ \\
8 & Ethyl Acetate $50 \mu \mathrm{g} / \mathrm{mL}$ & $20,42 \pm 1,909$ \\
9 & Ethyl Acetate $25 \mu \mathrm{g} / \mathrm{mL}$ & $24,58 \pm 0,722$ \\
10 & $\mathrm{n}$-Butanol $100 \mu \mathrm{g} / \mathrm{mL}$ & $37,92 \pm 4,018$ \\
11 & $\mathrm{n}$-Butanol $50 \mu \mathrm{g} / \mathrm{mL}$ & $48,75 \pm 1,250$ \\
12 & $\mathrm{n}$-Butanol $25 \mu \mathrm{g} / \mathrm{mL}$ & $58,33 \pm 1,443$ \\
13 & Dexa $5 \mu \mathrm{g} / \mathrm{mL}$ & $1,25 \pm 1,250$ \\
14 & Dexa $2,5 \mu \mathrm{g} / \mathrm{mL}$ & $3,75 \pm 1,250$ \\
15 & Control negative $(\mathrm{LPS})$ & $63,75 \pm 1,250$ \\
16 & Control normal & $0,83 \pm 0,722$
\end{tabular}

\section{Sample and Plant Identification}

Piper crocatum Ruiz and Pav were taken on Kebun Bunga street Palembang, carried out identification of red betel plants at the Andalas University Herbarium (ANDA) Department of Biology, Faculty of Mathematics and Natural Sciences, Andalas University Padang with collection number 106/K-ID/ANDA/II/2020

\section{Extraction and Fractionation}

Piper crocatum Ruiz and Pav dry powder $(600 \mathrm{~g})$ were macerated with methanol $(\mathrm{MeOH})(3 \times 2 \mathrm{~L})$ solvent for 48 hours. The macerate was evaporated in vacuo, and $93 \mathrm{~g}$ of thick extract was obtained. Eightythree grams of the viscous extract was fractionated with n-hexane, ethyl acetate and n-butanol as solvents, and each solvent was evaporated in vacuo with a rotary evaporator to obtain the thick fraction of n-hexane $(22 \mathrm{~g})$, ethyl acetate fraction $(20 \mathrm{~g})$ and viscous fraction $\mathrm{n}$-butanol $(8 \mathrm{~g})$.

\section{Cell Culture}

RAW 264.7 cells were grown in Dulbecco's Modified Eagle Medium (DMEM) supplemented with 10\% Fetal Bovine Serum (FBS) and 1\% penicillin-streptomycin solution. Cell cultures were incubated at $37^{\circ} \mathrm{C}$ in, humidified atmosphere and 5\% CO2 until the cells were confluent. Cells were then washed and harvested using trypsin-EDTA. ${ }^{11}$

\section{Cell Viability}

A cell viability test was carried out using the MTT test method on 264.7 RAW cells. A total of $1 \times 104$ cells per well were plated in 96 wells and then incubated for 24 hours at $37 \mathrm{oC}$. After 24 hours the medium was replaced with a new one and then added test solution (MEPC, HFPC, EAFPC, and BFPC), with a concentration of $200 ; 100 ; 50 ; 25 ; 12.5 \mathrm{~g} / \mathrm{mL}$ and dexamethasone $(20 ; 10 ; 5 ; 2.5 ; 1.25 \mathrm{~g} / \mathrm{mL})$. Incubate for 24 hours at $37^{\circ} \mathrm{C}$ in a $5 \% \mathrm{CO} 2$ incubator. At the end of incubation, the test medium and solution were removed, and the cells were washed with PBS. To each well, add $100 \mathrm{l}$ of culture medium and $10 \mathrm{~L}$ of $5 \mathrm{mg} / \mathrm{mL}$ MTT to each solution and incubate again for 4 hours. The formazan crystals formed were dissolved in $100 \mathrm{~L}$ DMSO. Absorption was measured using a microplate reader at a wavelength of $570 \mathrm{~nm} \cdot{ }^{12,13}$

\section{Nitric Oxide (NO) production test}

RAW 264.7 cells (1x104 cells/well) were grown on 96-well plates and incubated for 24 hours, added test solutions (MEPC, HFPC, EAFPC, and BFPC) with concentrations of $100,50,25 \mathrm{~g} / \mathrm{mL}$ and positive control (dexamethasone) with the concentration of $5,2.5 \mathrm{~g} / \mathrm{mL}$, negative control, and normal control. Then it was stimulated using LPS ( $1 \mathrm{~g} /$ $\mathrm{mL}$ ) and then incubated again for 24 hours in a 5\% CO2 incubator at $37 \mathrm{oC}$. The amount of nitrite in the culture medium was measured as an indicator of NO production. The amount of nitrite was calculated using NO assay kit reagent (Catalog No: E-BC-K035-M). Then, 100 $\mathrm{L}$ of the culture supernatant was added to $100 \mathrm{~L}$ of $\mathrm{NO}$ reagent and then incubated for 10 minutes in a dark room. The absorbance was measured at $550 \mathrm{~nm}$ on a microplate reader. The nitrite concentration was calculated using the sodium nitrite standard curve. ${ }^{14}$

\section{RESULTS}

\section{Cell Viability}

Cell viability test of RAW 264.7 on the administration of MEPC, EAFPC, HFPC and BFPC from red betel leaf showed a decrease in the number of live cells with increasing concentration. The concentration of the test substance is : $200 ; 100 ; 50 ; 25$ and $12.5 \mathrm{~g} / \mathrm{mL}$. Dexamethasone as a positive control with a concentration of $20 ; 10 ; 5$ and $2.5 \mathrm{~g} / \mathrm{mL}$.

\section{Production of Nitric Oxide (NO)}

The NO production test was carried out using the Nitric Oxide (NO) Colorimetric Assay Kit. Tests were carried out on MEPC, HFPC, EAFPC, and BFPC from red betel leaf at concentrations of 100, 50 and $25 \mathrm{~g} / \mathrm{mL}$, dexamethasone as a positive control at concentrations of 5 and $2.5 \mathrm{~g} / \mathrm{mL}$, negative control (LPS-induced cells), and standard control. (cells without LPS induction).

Graph of NO levels calculated from the n-hexane fraction, ethyl acetate fraction, butanol fraction, red betel leaf methanol extract and dexamethasone, normal and LPS-induced cells in RAW cells 264.7.

\section{DISCUSSION}

Cell viability test was carried out using the MTT method (3, 4, 5-dimethyltiazo 1-2-1-il)-2,5-diphenyl tetrazolium bromide assay to determine the non-toxic concentration of the n-butanol, ethyl acetate, n-hexane and methanol extract of Piper crocatum leaves Ruiz and Pav against 264.7 RAW cells. MTT assay is one of the quantitative tests to determine safe concentrations and is not toxic to cells used in research. The viability test results from MEPC, HFPC, EAFPC, and BFPC from Piper crocatum Ruiz and Pav leaves showed that the concentrations that gave the viability percentage above $80 \%$ were 100,50 and $25 \mathrm{~g} / \mathrm{mL}$ were used as concentrations for the inhibition test of NO production. Dexamethasone as a positive control, the concentrations were chosen were 5 and $2.5 \mathrm{~g} / \mathrm{mL}$ because they showed viability above $80 \% .^{15,16}$

\section{Production of Nitric Oxide (NO)}

The test of NO production in RAW 264.7 cells was carried out by inducing RAW 264.7 cells with lipopolysaccharide (LPS). Lipopolysaccharide is a substance derived from the outer membrane of gram-negative bacteria, which is an endotoxin that stimulates the release of inflammatory mediators such as NO, prostaglandins, cyclooxygenase. $\mathrm{NO}$ is a product produced by macrophages activated by LPS. The resulting NO production is measured as the concentration of nitrite in the culture medium, and NO is very easily oxidized to nitric (NO2) in the solution. The formed NO2 is added with diazotizing reagent (sulfanilamide) in an acidic medium to form a diazonium salt that reacts with a coupling reagent to form a stable colored azo compound. ${ }^{17}$ Cells induced with LPS released higher NO into the medium than cells not treated with LPS. ${ }^{18}$ The treated cells showed a decrease in the amount of NO. Treatment of cells with MEPC, HFPC, EAFPC, and BFPC at concentrations of 100, 50 and $25 \mathrm{~g} / \mathrm{mL}$ showed the ability to reduce $\mathrm{NO}$ production. 
The ethyl acetate fraction showed the most significant decrease in all the fractions tested for NO production in LPS-induced RAW 264.7 cells. The analyzed measurement data from each fraction was analyzed with one-way ANOVA statistics, showing different responses between treatment groups $\mathrm{p}<0.05(\mathrm{p}=0.000)$. The analysis continued with Duncan's test showing the ethyl acetate fraction with 100, 50 and 25 $\mathrm{g} / \mathrm{mL}$ concentration, giving the highest effect. This shows the ability of FEAPC at concentrations of 100,50 and $25 \mathrm{~g} / \mathrm{mL}$ to reduce NO production induced by larger LPS compared with EMPC, FHPC and FBPC at the same concentration.

\section{CONCLUSION}

Giving MEPC, HFPC, EAFPC, and BFPC of red betel leaf to RAW 264.7 cells induced by lipopolysaccharide at concentrations of $100 \mathrm{~g} /$ $\mathrm{mL}, 50 \mathrm{~g} / \mathrm{mL}, 25 \mathrm{~g} / \mathrm{mL}$ can reduce NO levels.

FEAPC from red betel leaf gave the best effect in reducing NO levels in RAW 264.7 cells induced by lipopolysaccharide.

\section{ACKNOWLEDGEMENTS}

This research was funded by the Directorate of Resources, Directorate General of Higher Education, Ministry of Education, Culture, Research and Technology through the multiple year basic research and capacity bulding in Higher Education 2021 with decree no 09/E1/KPT/2021 with main contracts no 104/E4.1/AK.04.PT/2021 and derivative contract T/5/UN.16.17/PT.01.03/PDD-Kesehatan/2021

\section{CONFLICTS OF INTEREST}

The authors have no conflicts of interest to declare.

\section{REFERENCES}

1. Katzung BG. Basic \& Clinical Pharmacology. 14th ed. New York, 2018.

2. Maldonado RF, Isabel S, and Valvano MA. Lipopolysaccharide modification in Gram-negative. FEMS Microbiol Rev. 2016; 40(4): 480-493.

3. Guzik TJ, Korbut R, and Adamek-Guzik T. Nitric oxide and superoxide in inflammation and immune regulation. J Physiol Pharmacol. 2003; 54(4): 469-487.

4. Manoi F. Sirih Merah sebagai Tanaman Obat Multifungsi. War. Puslitbangbun. 2007; 13(2): 275.

5. Fitriyani A, Winarti L, Muslichah S, and Nuri D. Uji antiinflamasi ekstrak metanol daun sirih merah (Piper crocatum Ruiz \& Pav) pada tikus putih. Maj Obat Tradis. 2011; 16(1): 2011.

6. Wahjuni S,Wita IW, and Astawa M. Anti-Inflammatory Effect of Red Piper Crocatum Leaves Extract Decrease TNF- $\alpha$ and IL-6 Levels in Wistar Rat with Atherosclerosis. Bali Med J. 2016; 5(2): 51-56.
7. Ehrich IN, Novalinda C, Girsang E, Dea E, Mardhotillah A, and Widowati W. Hepatoprotective properties of red betel ( Piper crocatum Ruiz and Pav ) leaves extract towards $\mathrm{H} 2 \mathrm{O} 2$-induced HepG2 cells via anti-inflammatory, antinecrotic, antioxidant potency. Saudi Pharm J. 2020; 28(10): 1182-1189.

8. Alfarabi M, Bintang M, Suryani, and Safithri MEGA. The Comparative Ability of Antioxidant Activity of Piper crocatum in Inhibiting Fatty Acid Oxidation and Free Radical Scavenging. HAYATI J Biosci. 2010; 17(4): 201-204.

9. Parfati N, Windono T. Sirih Merah (Piper crocatum Ruiz \& Pav .) Kajian Pustaka Aspek Botani, Kandungan Kimia, dan Aktivitas Farmakologi. Media Pharmaceutica Indonesiana 2016; 1(2) :106115

10. Arbain D, Nofrizal, Syafni N, Ismed F, Yousuf S, and Choudhary MI. Bicyclo[3.2.1]octanoid neolignans from Indonesian red betle leaves (Piper crocatum Ruiz \& Pav.). Phytochem Lett. 2018; 24: 163-166.

11. Hwang JH, Ma JN, Park JH, Jung HW, and Park YK. Antiinflammatory and antioxidant effects of MOK, a polyherbal extract, on lipopolysaccharide-stimulated RAW 264.7 macrophages. Int $J$ Mol Med. 2019; 43(1): pp 26-36.

12. Zheng L, Wang M, Peng $Y$, and LiX. Physicochemical Characterization of Polysaccharides with Macrophage Immunomodulatory Activities Isolated from Red Ginseng (Panax ginseng C . A . Meyer). J Chem. 2017: 1-8

13. Fan $C$, Wu LH, Zhang GF, Xu F, Zhang S, Zhang $X$, Sun L, Yu Y, Zhang $Y$, Ye RD. 4'-Hydroxywogonin suppresses lipopolysaccharideinduced inflammatory responses in RAW 264.7 macrophages and acute lung injury mice. PLoS One. 2017; 12(8): 1-17.

14. He J, Lu X, Wei T, Dong Y, Cai Z, Tang L, Menghua Liu M. Asperuloside and Asperulosidic Acid Exert anAnti-Inflammatory Effect via Suppression of theNF-KB and MAPK Signaling Pathways inLPSInduced RAW 264.7 Macrophages. Int J Molecular Sci. 2018; 19: 2027

15. Hikariastri $P$, Winarno $H$, Kusmardi $K$, Laksmitawati DR, and Abdillah S. Aktivitas Antiinflamasi Crude Extract Fukoidan dari Sargassum crassifolium pada Sel RAW 264.7 yang Diinduksi LPS. Jurnal Kefarmasian Indonesia. 2019; 9(2): 97-105.

16. Laksmitawati $D R$, Widyastuti $A$, Karami, Afifah $E$, Rihiba DD, Nufus $\mathrm{H}$, Woidowati W. Anti-inflammatory effects of Anredera cordifolia and piper crocatum extracts on lipopolysaccharide-stimulated macrophage cell line. Bangladesh J Pharmacol. 2017; 12(1): 35-40.

17. Sun J, Zhang $X$, Broderick M, Fein H. Measurement of Nitric Oxide Production in Biological Systems by Using Griess Reaction Assay. Sensors. 2003; 3(8): 276-284

18. Joo T, Sowndhararajan K, Hong S, Lee J, Park SY, Kim S, Jhoo JW Inhibition of nitric oxide production in LPS-stimulated RAW 264 . 7 cells by stem bark of Ulmus pumila L . Saudi J Biol Sci. 2014; 21(5): 427-435. 


\section{GRAPHICAL ABSTRACT}

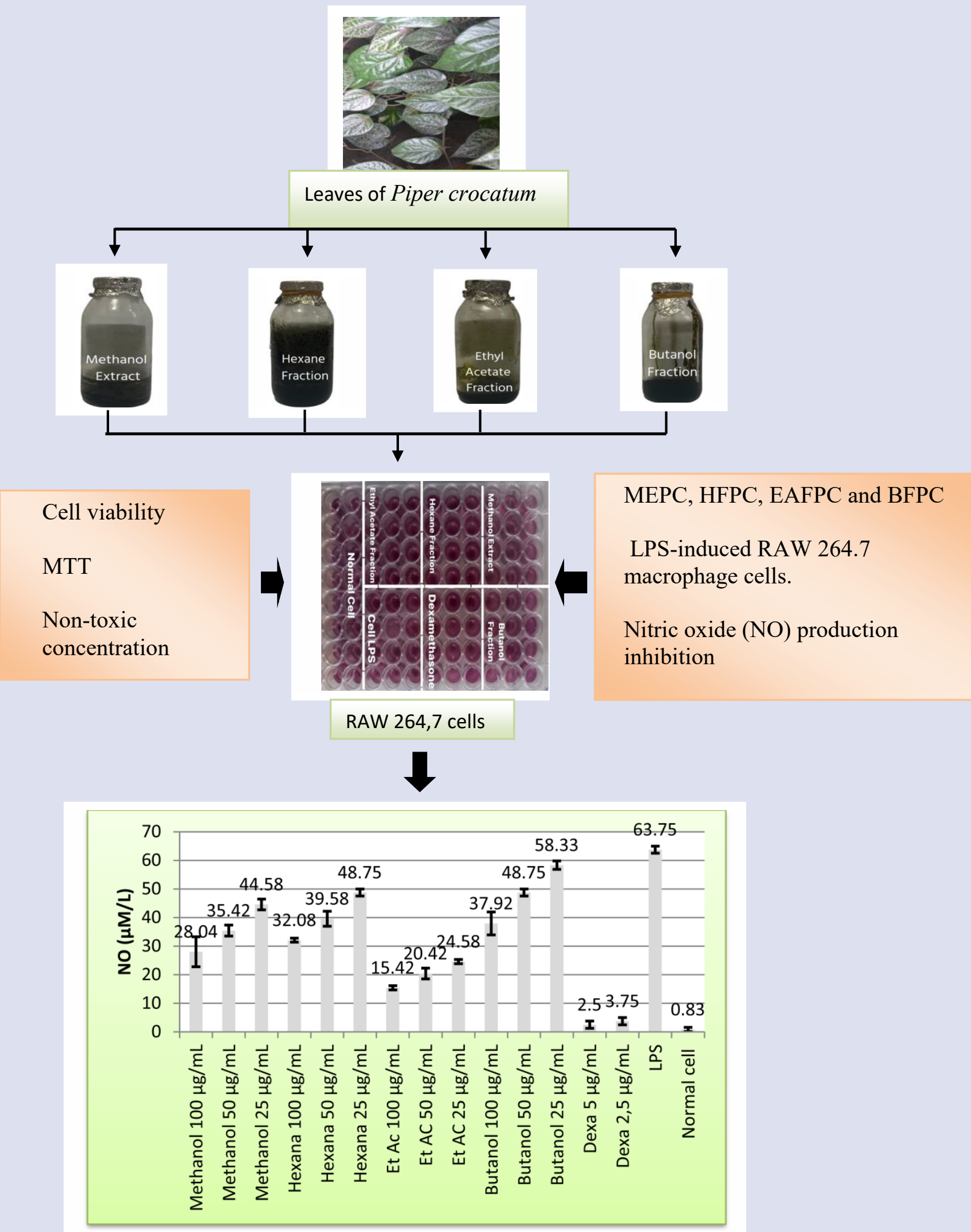

NO levels of MEPC, HFPC, EAFPC, and BFPC, dexamethasone, and normal cell in LPS-induced RAW 264.7 cells 


\section{ABOUT AUTHORS}
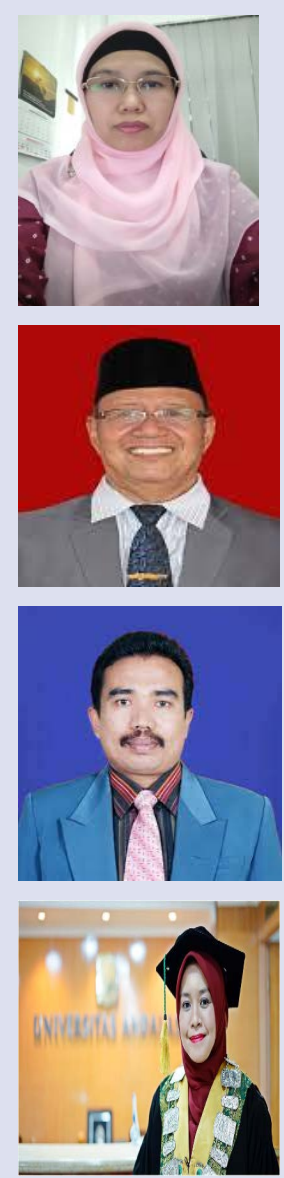

Nilda Lely She is a student of the Faculty of Pharmacy, Andalas University who has been involved in research studying the activity of the Anti-Inflammatory Effects of Methanol Extract, Hexane, Ethyl Acetate, and Butanol Fraction of Piper crocatum Ruiz \& Pav Leaves on Lipopolysaccharide-induced RAW 264.7 Cells.

Prof. Helmi Arifin, is a Professor of Pharmacology at the Faculty of Pharmacy, Andalas University, Indonesia. He is the former dean of the faculty of Pharmacy. His research is mostly focusing on the investigation of medicinal plants effect for disease complications.

Prof. Dr. Yufri Aldi, M.Si, Apt. He is as a lecturer at the Faculty of Pharmacy, Andalas University. Graduated from the Faculty of Pharmacy, Andalas University in 1989, then the Master's Program in 1994 at the Bandung Institute of Technology School of Pharmacy (ITB) and the Doctoral Program in the Biomedical Department, Faculty of Medicine, Andalas University in 2013. Research and expertise in Pharmacolmmunology. Currently working as Head of the Department of Pharmacy Doctoral Program, Faculty of Pharmacy, Andalas University

Prof. Dr. Fatma Sri Wahyuni, Apt. She is a lecturer at the Faculty of Pharmacy, Andalas University. Got her undergraduate degrees from Andalas University in 1998 and finished her $\mathrm{PhD}$ from University Putra Malaysia in 2010. Her research is focusing on pharmacological activity studies of Sumatran Plants.

Cite this article: MLely N, Arifin H, Aldi Y, Wahyuni FS. Anti-Inflammatory Effects of Methanol Extract, Hexane, Ethyl Acetate, and Butanol Fraction of Piper crocatum Ruiz \& Pav Leaves on Lipopolysaccharide-induced RAW 264.7 Cells. Pharmacogn J. 2021;13(6): 1341-1346. 